УДК: 631.41

\title{
PHYSICAL, CHEMICAL AND BIOCHEMICAL PROPERTIES OF WESTERN SIBERIA SPHAGNUM AND CAREX PEAT SOILS
}

\author{
Szajdak L.W. ${ }^{\text {I) }}$, Lapshina E.D. ${ }^{2)}$, Gaca W. ${ }^{\text {I) }}$, Styła K. ${ }^{\text {I) }}$, Meysner T. ${ }^{\text {I) }}$, \\ Szczepański M. ${ }^{1)}$, Zarov E.A. ${ }^{2)}$ \\ ${ }^{1)}$ Institute for Agricultural and Forest Environment, Poznań, Poland \\ ${ }^{2)}$ Yugra State University, Khanty-Mansiysk, Russian Federation
}

lech.szajdak@isrl.poznan.pl

Comparative study of physical, chemical and biochemical properties has been carried out in acrotelm and catotelm of Sphagnum and Carex dominated peat soils in Western Siberia. Concentration of total nitrogen is directly proportional to ammonium and nitrates ions, activity of urease, bulk density and inversely proportional to C/N, porosity and moisture in both peat soils. The data received indicate lower rate of nitrogen transformation and decrease processes of organic matter decomposition in Sphagnum than in Carex dominated peat soils. The studies showed that organic matter from Sphagnum dominated peat soils has undergone the most significant biochemical and chemical transformation (oxidation, hydrolysis, polymerization) with the accumulation of resistant compounds compared to the organic matter from Carex dominated peat soils.

Key words: Sphagnum and Carex peats soils, enzymatic activity, physical, chemical and biochemical properties.

Citation: Szajdak L.W., Lapshina E.D., Gaca W., Styła K., Meysner T., Szczepański M., Zarov E.A. 2016. Physical, chemical and biochemical properties of Western Siberia Sphagnum and Carex peat soils // Environmental dynamics and global climate change. V. 7. No. 2. P. 13-25.

\section{INTRODUCTION}

A great majority of present-day peatlands originated in the last 15,000 years. It is estimated that 4 million $\mathrm{km}^{2}$ on Earth (some $3 \%$ of the land area) is covered with peatlands [Joosten and Clarke, 2002]. Over $90 \%$ of peatlands are in the temperate and cold belt in the Northern Hemisphere (Western Siberia, Canada and Alaska, and Northern Europe). The remaining area is located in tropical and sub-tropical latitudes, much of it under forest (Southeast Asia, and parts of the Amazon basin) [Lappalainen, 1996].

West Siberian Lowland is the largest wetland area of the world. The total area of $0.6-1.0 \times 10^{6} \mathrm{~km}^{2}$ of the West Siberian peatlands contains a carbon pool of 51-70 Pg C $\left(\mathrm{Pg}=10^{15} \mathrm{~g}\right)$. These values represent 18$30 \%$ of the area and 11-15\% of the peat carbon pool of all boreal and subarctic peatlands [Repo et al., 2007].

However, low rate of peat mineralization, the relative humidity and cool climate accompanied by poor drainage across the flat terrain has maintained accumulation of organic matter and development of an important carbon pool [Dobrovol'skaya et al., 2014]. Peat accumulation generally takes place as a result of limited decomposition of plant material. An important factor for peat accumulation is the chemical and structural composition of the organic material, which determines its "ability to decay". However, water seems to be the most important external factor limiting decay. The ability to decay varies with species, plant part, chemical and biochemical compounds. This means that some plant species, organs, and compounds are more inclined to accumulate peat than others. A large number of plant species occurring in mires can contribute to peat formation, such as Sphagnum and some other mosses, sedges, grasses and woody plants. Consequently, a wide variety of "botanical" peat types exists. Thus, botanical composition, relative amounts of the main plant species or species groups is the fundamental property for determining the nature of peat and the physical, chemical and biochemical properties of the peat.

Sphagnum (moss) and Carex (sedge) are typical peat forming plant species. They form peat in different ways. Sphagnum moss grows from the apical bud and respectively lower layers die and form peat [Mäkilä, 2011a]. The Sphagnum litter decomposes more slowly than leaves of most other plants in their natural habitats. However, low concentration of nitrogen, acid conditions which are produced by the Sphagnum itself and wet environment are the most common reasons for above processes. Sphagnum mosses produce nutrient poor, recalcitrant litter that is enriched in organic compounds (e.g. uronic acids) and polyphenols, thus inhibiting microbial activity and depressing vascular plant growth, fundamentally 
influencing bog biogeochemistry [van Breemen, 1995; Clymo and Hayward, 1982]. In Sphagnum primary production ranged from 10 to $500 \mathrm{~g} \mathrm{~m}^{-2} \mathrm{yr}^{-1}$ depending of the plant species and localization [Mäkilä and Goslar, 2008].

In Carex peat soils (and also in the formation of other high plants), the most important constituents are roots [Mäkilä, 2011a]. Certain proportion of roots dies and regenerates, so besides living roots, there are roots of different ages in the same peat volume. Finally, all roots die and form peat [Mäkilä, 2011a]. Williams et al. [2000] demonstrated that in Carex lack condensed tannins, which are typical inhibitors. In Carex dominated boreal peatlands the primary production may exceed $1000 \mathrm{~g} \mathrm{~m}^{-2} \mathrm{yr}^{-1}$ [Mäkilä and Goslar, 2008].

Peatlands are characterised biophysically by two horizons, the surface acrotelm and the deeper catotelm. The acrotelm layer is located $10-50 \mathrm{~cm}$ from the base of the euphotic layer [Clymo, 1992]. The acrotelm has a high hydraulic conductivity, variable water content and consists of living and undecomposed dead plant material. Upper layer is rich in peat-forming aerobic bacteria and other microorganisms and has a live matrix of growing plant material. As litter and new peat in the acrotelm are exposed to oxygen and varying water levels, they are subject to a relatively high decay rate. However, in comparison with acrotelm the catotelm has water content invariable with time, a small hydraulic conductivity, is not subject to air entry and is devoid of peat-forming aerobic microorganisms. In the deeper layer, the decay rate declines sharply and becomes less dependent on surface environmental conditions over time [Nungesser, 2003; Holden and Burt, 2003].

Enzymes in soil play an important role in catalyzing reactions indispensable in life processes of soil microorganisms, decomposition of organic residues, forming organic matter and soil structure as well as circulation of nutrients [Sinsabaugh et al., 2008]. Savicheva and Inisheva [2008] postulated that organic matter transformations in peat soils are performed by enzymes from the classes of hydrolases and oxidoreductases. In peat soils waterlogged conditions might limit enzyme activity by changes in the microbial community and increased concentrations of inhibitors such as $\mathrm{Fe}(\mathrm{II})$ [Kang and Freeman, 1999].

There is a lot of data focused on the differences between Sphagnum and Carex dominated peat soils in the literature. However, a lot of research currently refers to botanical composition, accumulation of organic matter and the release of $\mathrm{CO}_{2}, \mathrm{CH}_{4}$ of West Siberia peatlands. Limited information concerning physical, chemical and biochemical properties between Sphagnum and Carex dominated peat soils in Western Siberia is available in the literature. Furthermore, the knowledge about physical, chemical parameters and enzymes in Sphagnum and Carex dominated peat soil of Western Siberia is still poorly documented and understood. Thus, the study was conducted to show the impact of two typical peat forming plant species - Sphagnum and Carex on physical, chemical and biochemical properties of peat soils in Western Siberia at two different depths $(0-50 \mathrm{~cm}$ and 50-100 $\mathrm{cm})$. Therefore, the study should increase the knowledge about these processes and mechanisms in Sphagnum and Carex dominated peat soils.

\section{MATERIALS AND METHODS}

Nine peatland sites differing in type of peat and botanical composition situated in West Siberia (Russia) near Mukhrino Field Station have been investigated. GPS parameters and location of all investigated peatlands are included in fig. 1, Appendix, table 1. Mukhrino Field Station is located at the west bank of the Irtysh River near the confluence with the Ob River in the central taiga subzone of West Siberian, $26 \mathrm{~km}$ west of the town of Khanty-Mansiysk. This area is owned and run by the UNESCO Chair on Environmental Dynamics and Climate Change at the Yugra State University, Khanty-Mansiysk, Russia.

Due to severe continental climate, the environmental conditions in the region are comparable with the sub-arctic zone of Northern Europe (fig. 1; table 1). Thickness of peat deposit ranges from 1.0 to $4.0 \mathrm{~m}$. The vegetation of Mukhrino mire is presented in table 1. The investigated materials were peat samples collected from eleven of Sphagnum, and Carex dominated peat soils. In the research area the total annual precipitation equals to $530.6 \mathrm{~mm}$ and the average annual air temperature is $-1.12^{\circ} \mathrm{C}$. On average of the vegetation season lasts about 120 days.

The peat samples were taken in 2012 from above-mentioned investigated points. Samples were collected with the Instorf sampler (container length $50 \mathrm{~cm}$ ) from 0 to $50 \mathrm{~cm}$ (acrotelm) and from 50 to 100 $\mathrm{cm}$ (catotelm) depths in the stratigraphic profile of each peat deposit. The peat soil samples were wrapped in aluminum foil and transported to the laboratory at ca. $4^{\circ} \mathrm{C}$ and stored at $-20^{\circ} \mathrm{C}$. The samples were dried at $20^{\circ} \mathrm{C}$, sieved through $1 \mathrm{~mm}$ mesh in order to remove large particles and undecomposed plant debris, and stored prior to analysis. 


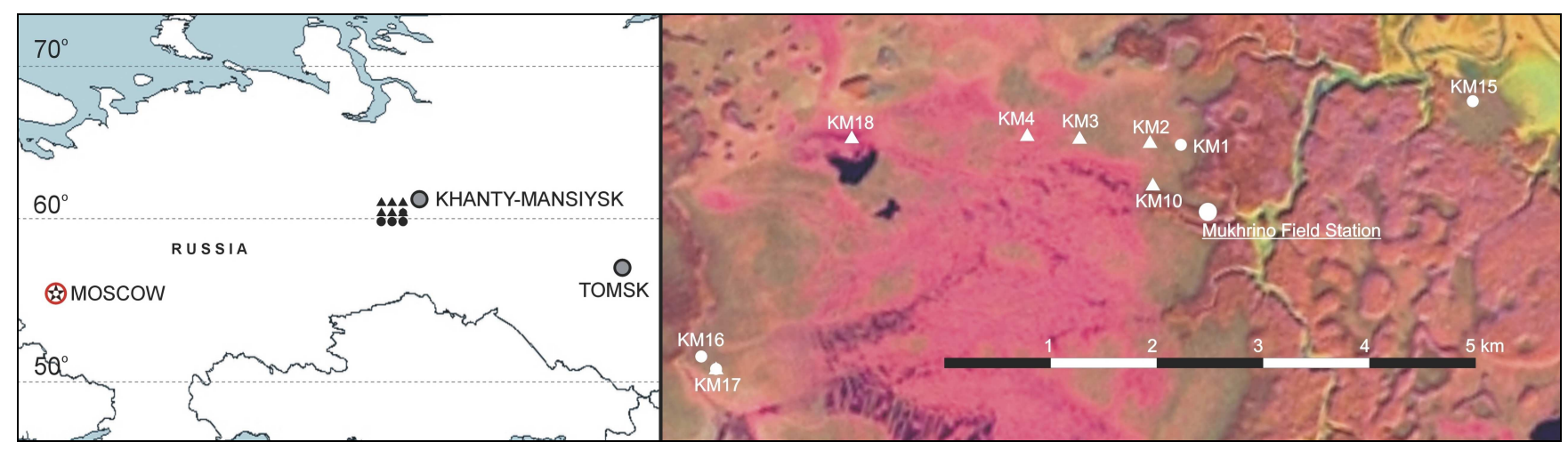

Fig. 1. Setting of the study site (Landsat image - band 453) A Sphagnum dominated peat soils: Mukhrino Field Station: KM2, KM3, KM4, KM10, KM17 (0-50 cm), KM18 • Carex dominated peat soils: Mukhrino Field Station: KM1, KM15, KM16, KM17 (50-100 cm)

The degree of decomposition or humification of the peat is assessed by measuring its fiber or humus content. In practice, peat decomposition is determined by a field method (von Post pressing method) [von Post, 1922; Szajdak et al., 2011c]. The method identifies ten classes of decomposition, with H1 being undecomposed peat and H10 completely decomposed peat.

$\mathrm{pH}$ was measured in $1 \mathrm{~N} \mathrm{KCl}$ and in water $(1: 20 \mathrm{v} / \mathrm{v})$ suspensions by potentiometric method. Soil bulk density was estimated from the soil organic matter concentration. The soil samples were dried at $105^{\circ} \mathrm{C}$ and ashed at $550^{\circ} \mathrm{C}$ using a muffle furnace. Bulk density was determined in soils mass per unit volume of soil [Okruszko and Piaścik, 1990]. Porosity was calculated from the bulk density ratio of the soil to the density of solids. Density of solids was calculated from equation [Okruszko and Piaścik, 1990]

$$
\mathrm{DS}=0.011 \mathrm{~A}+1.451
$$

where: DS - density of solids, A - ash content.

The total organic carbon (TOC) was analyzed on Total Organic Carbon Analyzer (TOC 5050A) with Solid Sample Module (SSM-5000A) produced by Shimadzu (Japan). Dissolved organic carbon (DOC) was evaluated on TOC 5050A equipment produced by Shimadzu (Japan). For the investigation of DOC soil samples were heated in deionized water at $100^{\circ} \mathrm{C}$ for two hours under a reflux condenser. Extracts were filtered through $0.45 \mu \mathrm{m}$ pore-size filters and analyzed on TOC 5050A facilities [Smolander and Kitunen, 2002]. Total nitrogen was evaluated by the Kjeldahl methods.

Ammonium ions were measured on ion chromatograph Waters 1515 (USA) equipped with a 1515 Isocratic HPLC pump, conductivity detector Waters 432, a rotary valve fitted with $20 \mu \mathrm{L}$ sample loop and column PRP-X200 (150 x 4.1 mm I.D.) from Hamilton, protected with a guard column of the same material ( 25 x $2.3 \mathrm{~mm}$ I.D.). Nitrate ions were determined on ion chromatograph HIC-6A Shimadzu (Japan) equipped with a LP-6A Isocratic HPLC pump, conductivity detector CDD-6A, a rotary valve fitted with $20 \mu \mathrm{L}$ sample loop and column PRP-X100 (150 x $4.1 \mathrm{~mm}$ I.D.) column from Hamilton, protected with a guard column of the same material ( $25 \times 2.3 \mathrm{~mm}$ I.D.). Nitrate and ammonium ions as nitrogen were assayed in the same water extracts with an ion chromatograph [Szajdak and Gaca, 2010].

The ferrous ions in soils were determined by phenanthroline method [Minczewski and Marczenko, 1976; Szajdak et al., 2011a; Szajdak et al., 2011b]. The concentrations of ferrous ions were estimated colorimetrically at $\lambda_{\max }=512 \mathrm{~nm}$ on UV-VIS spectrophotometer Beckman DU ${ }^{\circledR}-68$ USA. Deionized water was used as blank. The ferric ions were measured by thiocyanate technique [Minczewski and Marczenko, 1976; Szajdak et al., 2011a; Szajdak et al., 2011b]. The content of ferric ions was determined colorimetrically at $\lambda_{\max }=480 \mathrm{~nm}$ on UV-VIS spectrophotometer Beckman DU ${ }^{\circledR}-68$ USA. Deionized water was used as blank.

Urease [EC 3.5.1.5] activity was evaluated by Hoffmann and Teicher method [Szajdak et al., 2002; Szajdak et al., 2011a; Szajdak et al., 2011b]. This method involves determination of the ammonium released by urease when soil is incubated with buffered $(\mathrm{pH}=6.7)$ urea solution and toluene at $37^{\circ} \mathrm{C}$ for $3 \mathrm{~h}$. The absorbance of the solution was measured colorimetrically at $\lambda_{\max }=630 \mathrm{~nm}$ using a UV-VIS spectrophotometer Beckman DU ${ }^{\circledR}-68$ USA.

Xanthine oxidase [EC 1.17.3.2] activity was measured by Krawczyński method [Krawczyński, 1972; Szajdak et al., 2011a; Szajdak et al., 2011b]. Xanthine is used as a substrate for measurement of activity of the xanthine oxidase in fresh soil samples. The absorbance of the solution was measured colorimetrically at $\lambda_{\max }=290 \mathrm{~nm}$ using a UV-VIS spectrophotometer Beckman DU ${ }^{\circledR}-68$ USA. 
Phenol oxidase [EC 1.14.18.1] activity was determined by Perucci method [Perucci et al., 2000; Szajdak et al., 2011a; Szajdak et al., 2011b]. Catechol is used as a substrate for measurements of phenol oxidase activity in fresh soil samples. The absorbance of the solution was measured colorimerically at $\lambda_{\max }=525 \mathrm{~nm}$ using a UV-VIS spectrophotometer Beckman DU ${ }^{\circledR}$-68 USA.

Peroxidase [EC 1.11.1.7] activity in soils was assayed by Bartha and Bordeleau method [Bartha and Bordeleau, 1969; Szajdak et al., 2011a; Szajdak et al., 2011b]. Peroxidase activity was estimated by following the $\mathrm{H}_{2} \mathrm{O}_{2}$-mediated oxidation of $o$-dianisidine. The absorbance of the solution was measured colorimetrically at $\lambda_{\max }=460 \mathrm{~nm}$ using a UV-VIS spectrophotometer Beckman DU ${ }^{\circledR}-68$ USA.

Nitrate reductase [EC 1.7.99.4] activity was determined using potassium nitrate as a substrate and 2,4dinitrophenol as inhibitor of nitrite reductase according to Kandeler [1996]. The field-moist soil samples were incubated for $24 \mathrm{~h}$ at $25^{\circ} \mathrm{C}$ under waterlogged conditions in test tubes. Nitrite released as a result of incubation was extracted with potassium chloride solution and determined colorimetrically at $\lambda_{\max }=520 \mathrm{~nm}$ [Szajdak and Gaca, 2010; Szajdak and Gaca, 2011; Szajdak et al., 2011a].

All chemical and biochemical analyzes were run in triplicate, and the results were averaged. The confidence intervals were calculated using the following formula: $\bar{x} \pm \mathrm{t}_{\alpha \cdot(\mathrm{n}-1)} \mathrm{SE}$, where: $\bar{x}$ - mean; $\mathrm{t}_{\alpha \cdot(\mathrm{n}-1)}-$ value of the Student test for $\alpha=0.05 ; \mathrm{n}-1$ - degree of freedom, SE - standard error. All the chemicals used in this study were of analytical grade of purity.

\section{RESULTS AND DISCUSSION}

\section{Acidic conditions and moisture}

Both peat soils revealed acidic conditions (Appendix, table 2). Values of $\mathrm{pH}_{\mathrm{KCl}}$ ranged from 2.40 to 3.28 in Sphagnum dominated peat soils, whereas in Carex dominated peat soils were slightly higher between 3.72 and 4.43 (table 2). However, $\mathrm{pH}$ measured in $\mathrm{H}_{2} \mathrm{O}$ was from 3.14 to 4.02 in Sphagnum dominated peat soils and from 4.15 to 5.32 in Carex dominated peat soils. However, Golovchenko et al. (2007) demonstrated the $\mathrm{pH}$ of the saline exratct varied between 2 and 4 in ombrotrophic peatlands (shrubby-sedge-sphagnum) and Błońska (2010) indicated lowest $\mathrm{pH}_{\mathrm{KCl}}(2.74)$ in Sphagnum.

The moisture of Sphagnum was statistically significant higher than in Carex dominated peat soils of acrotelm and catotelm (table 2). The moisture content of the moss is directly related to its thermal conductivity which changes ten-fold between dry and saturated conditions.

\section{Bulk density and porosity}

Our studies revealed that the bulk density increases with the depth in Sphagnum, but decreases with the depth in Carex dominated peat soils (table 2). Bulk densities were statistically significant lower in Sphagnum (98.17-105.80 $\mathrm{kg} \cdot \mathrm{m}^{-3}$ ) than in Carex $\left(114.00-157.67 \mathrm{~kg} \cdot \mathrm{m}^{-3}\right)$ dominated peat soils of acrotelm and catotelm (table 2). Moreover, it was observed the impact of the kind of peats on the differences in porosity. The values of porosity for Sphagnum dominated peat in both depth of sampling were statistically significant higher (92.57-93.00\%) than in Carex dominated peat soils $(88.88-91.90 \%)$ (table 2). These data suggest lower decomposition degree in Sphagnum than in Carex dominated peat soils, because decay can also result in an increase of the dry bulk density. According to Bozkurt et al. [2001] the bulk density at first decreases with the depth because of decomposition without compression, and later increases, as compression becomes the dominant factor. Paavilainen and Päivänen [1995] showed in Sphagnum peat a positive and approximately linear regression between bulk density and the von Post humification scale value. In addition, Borren et al. [2004] postulated lower dry bulk density in ombrotrophic Sphagnum fuscum deposit of the bog than in the minerotrophic herb-moss deposits. Moreover, Mäkilä [2011b] demonstrated lower bulk density in coastal Sphagnum bogs than in Carex appa mire.

\section{Carbon content}

Data presented in table 2 showed no statistically significant differences of the TOC concentrations between Sphagnum and Carex dominated peat soils in both layers. The amount of TOC in acrotelm was $413.68 \pm 8.45 \mathrm{~g} \mathrm{~kg}^{-1}$ and in catotelm was $437.54 \pm 9.00 \mathrm{~g} \mathrm{~kg}^{-1}$ in Sphagnum dominated peat soils. In Carex dominated peat soils the content of TOC in acrotelm was $416.93 \pm 16.65 \mathrm{~g} \mathrm{~kg}^{-1}$ and in catotelm was $447.45 \pm 13.73 \mathrm{~g} \mathrm{~kg}^{-1}$. Our data are in line with the results of Bejger et al. [2011]. These authors reported no significant differences of organic carbon concentration between Sphagnum and Carex peat soils.

Inisheva et al. [2011], Mäkilä [2011b], Savelyeva and Yudina [2003] and Arkhipov and Maslov [1998] proved that the content of organic carbon in Sphagnum was lower than in Carex dominated peat soils. 
However, these authors have not shown statistically significant differences in carbon values between Sphagnum and Carex peat soils.

Koerselman et al. [1993] detected higher concentration of organic matter in Sphagnum than in Carex soils, and between these data no statistically significant differences were observed.

Moreover, Beilman et al. [2009] and Robinson and Moore [1999] evaluated statistically significant lower amounts of organic carbon in Sphagnum than in sedge peat.

In addition, our previous study in Polish peat soils confirmed higher concentrations of TOC in raised bog (from 606.26 to $636.75 \mathrm{~g} \cdot \mathrm{kg}^{-1}$ ) than in fen (from 509.95 to $607.85 \mathrm{~g} \cdot \mathrm{kg}^{-1}$ ) [Szajdak et al. 2012a; Szajdak et al. 2012b].

The content of DOC in our samples of Sphagnum $\left(14.67 \mathrm{~g} \cdot \mathrm{kg}^{-1}\right)$ was statistically significant higher than in Carex dominated peat soils $\left(10.12 \mathrm{~g} \cdot \mathrm{kg}^{-1}\right)$ in catotelm (table 2). These outcomes are in line with Ulanowski and Branfireun [2013], who confirmed that Carex dominated surface pore-waters had statistically significant lower DOC concentrations than Sphagnum dominated peat soils. Also, higher results of DOC found Chanton et al. [2008] in bog sites dominated by Sphagnum and woody plants than in fen sites dominated by sedges, further indicating lower reactivity of DOC at the Sphagnum and woody plant sites. Furthermore, Szajdak et al. [2012a and 2012b] indicated the increase of the concentration of DOC in raised bog (from 11.38 to $15.60 \mathrm{~g} \cdot \mathrm{kg}^{-1}$ ) in comparison with fen (from 4.87 to $11.24 \mathrm{~g} \cdot \mathrm{kg}^{-1}$ ) in Polish peatlands.

\section{Nitrogen}

Our results showed statistically significant lower total nitrogen in Sphagnum (from 11.16 to 12.10 $\mathrm{g} \cdot \mathrm{kg}^{-1}$ ) than in Carex (from 13.66 to $16.13 \mathrm{~g} \cdot \mathrm{kg}^{-1}$ ) dominated peat soils in acrotelm and catotelm (table 2). These data are in line with Scheffer et al. [2001], who indicated lower concentration of total nitrogen in Sphagnum squarrosum than Carex diandra. In addition, Glenn et al. [2006] proved that total nitrogen in Sphagnum spp. at the poor fen was lower than half in relation to Carex lasiocarpa at the extreme-rich fen. Moreover, in Polish peatlands was observed higher content of total nitrogen in fen (from 18.48 to $22.96 \mathrm{~g} \cdot \mathrm{kg}^{-}$ ${ }^{1}$ ) than in raised bog (from 8.96 to $13.16 \mathrm{~g} \cdot \mathrm{kg}^{-1}$ ) [Szajdak et al., 2012a and 2012b]. Total nitrogen deposition is usually divided into a wet and a dry component, and includes deposition of inorganic inputs of $\mathrm{NO}_{\mathrm{x}}$ and $\mathrm{NH}_{\mathrm{y}}$ as well as organic inputs, such as the nitrogen in pollen, amino acids, and organic nitrates [Limpens et al., 2006]. According to Malmer and Wallén [2005] low availability of N and P in Sphagnum-mires results partly from low mineralization rates and partly from the losses associated with the formation of peat. Furthermore, Aerts et al. [1999] found that low-N concentrations are responsible for the slow decomposition of Sphagnum tissue. In addition, Savicheva and Inisheva [2008] suggested that the processes of biochemical degradation are significantly affected by nitrogen-containing compounds. Westbrook et al. [2006] showed that the total nitrogen content varies from 1.17 to $2.80 \%$ in peat soils. This author revealed that dynamic of peatland nitrogen is driven by their hydrological condition and thus tend to exhibit high spatial variation in nitrogen cycling processes. High soil moisture and degree of soil anoxia has been shown to increase soil nitrogen availability of post-harvest in peatland. Additionally, altered soil microclimate and peat disturbance lead to higher nitrogen cycling rates in peatlands following harvest.

Our investigations showed statistically significant higher amounts of ammonium at the depth of 0-50 $\mathrm{cm}\left(37.86 \mathrm{mg} \cdot \mathrm{kg}^{-1}\right)$ and $50-100 \mathrm{~cm}\left(28.94 \mathrm{mg} \cdot \mathrm{kg}^{-1}\right)$ in Carex, than in Sphagnum (acrotelm $25.30 \mathrm{mg} \cdot \mathrm{kg}^{-1}$, catotelm $18.64 \mathrm{mg} \cdot \mathrm{kg}^{-1}$ ) dominated peat soils (table 2). However, nitrate ions were from 22.78 to 32.14 $\mathrm{mg} \cdot \mathrm{kg}^{-1}$ in Carex and from 15.96 to $26.53 \mathrm{mg} \cdot \mathrm{kg}^{-1}$ in Sphagnum dominated peat soils for both layers. The previous study of Szajdak et al. [2012a and 2012b] demonstrated higher content of ammonium and nitrate ions in raised bog than in fen in Polish peatlands. Nitrate export following harvest results from increased ammonification (degradation of organic nitrogen compounds with the formation of ammonium) and nitrification $\left(\mathrm{NH}_{4}{ }^{+}\right.$oxygenation to $\left.\mathrm{NO}_{3}{ }^{-}\right)$in conjunction with drastically reduced vegetative nitrogen uptake [Spoelstra et al., 2010]. $\mathrm{NH}_{4}{ }^{+}$is likely to be immobilized by the microbial biomass because of high $\mathrm{C} / \mathrm{N}$ ratio of Sphagnum whereas $\mathrm{NO}_{3}{ }^{-}$can also be denitrified thus raising $\mathrm{N}$ released to the atmosphere as either $\mathrm{N}_{2} \mathrm{O}$ or $\mathrm{N}_{2}$, modifying the N sink capacity of Sphagnum-mires [Francez et al., 2011].

The C/N ratio was statistically significant higher in Sphagnum (34.19 and 39.20) than in Carex dominated peat soils (27.74 and 30.52) (table 2) in acrotelm and catotelm. These values of C/N suggest a lower decomposition degree of organic residues in Sphagnum than in Carex dominated peat soils. Scheffer et al. [2001] showed slower degradation of litter in Sphagnum than in Carex, which was caused by intrinsic differences in litter quality and not by the environment.

\section{Iron content}


In addition, the results of our study showed no statistically significant differences for $\mathrm{Fe}(\mathrm{II})$ and $\mathrm{Fe}_{\text {total }}$ concentrations between Sphagnum and Carex dominated peat soils in both layers (table 2). Whereas, Fe(III) content was statistically significantly higher in Sphagnum $\left(37.98 \mathrm{mg} \cdot \mathrm{kg}^{-1}\right)$ than in Carex $\left(26.18 \mathrm{mg} \cdot \mathrm{kg}^{-1}\right)$ in catotelm. Higher concentrations of Fe(III) in Sphagnum than in Carex dominated peat soils suggest higher oxygenic properties in Sphagnum dominated peat soils. Steinmann and Shotyk [1997] observed the increase of the amount of $\mathrm{Fe}$ (II) and Fe(III) with the depth in Sphagnum dominated peat. One possible explanation for the relatively high concentrations of $\mathrm{Fe}$ (III) in catotelm is the complexation of $\mathrm{Fe}$ (III) by organic ligands such as humic substances. According to Lovley and Anderson [2000] dissimilatory iron (III) reduction significantly influence the fate of both organic and inorganic compounds in pristine and contaminated subsurface environments. In deep pristine aquifers iron (III) reduction can be an important processes for oxidation of organic matter, increasing the concentrations of dissolved inorganic carbon and dissolved iron (II) while at the same time preventing the accumulation of sulfide. The major differences between Sphagnum and Carex peat were found to derive from the habitat conditions at the time of peat formation. Carex peats are formed exclusively in fen and most often in nutrient-rich peatlands with high $\mathrm{pH}$ and a high microbial activity [Ringqvist and Öborn, 2002]. Decomposition of organic matter without removal of an element will lead to a gradual increase in the concentration with time. If such conditions exist in a peat profile the element will increase with depth. In contrast, a decrease in the concentration with depth or the presence of an accumulation horizon indicates on the translocation of the element [Bozkurt et al., 2001].

\section{Enzymes}

Soil enzymes play key biochemical functions in the overall process of organic matter humification and decomposition in the soil system. The rate of decomposition is mainly determined by the degradability of the litter and enzymes as biotic factors and $\mathrm{pH}$, humidity, temperature, oxygen availability as abiotic factors. According to Mäkilä and Goslar [2008] peat-forming species differ in their capacities for formation and decay of peat.

Statistically significant lower activity of urease was determined in acrotelm and catotelm of Sphagnum (1.98 and $\left.2.52 \mu \mathrm{mol} \cdot \mathrm{s}^{-1} \cdot \mathrm{kg}^{-1}\right)$ than in Carex dominated peat soils $\left(2.60\right.$ and $\left.2.81 \mu \mathrm{mol} \cdot \mathrm{s}^{-1} \cdot \mathrm{kg}^{-1}\right)$ in West Siberian peatlands. It suggests lower rate of nitrogen transformation in Sphagnum than in Carex dominated peat soils (Appendix, table 3). Lower activities of urease in Sphagnum than in Carex dominated peat soils are in line with the values of bulk density, ammonium, nitrates, and total nitrogen. According to early study of Szajdak et al. [2013] the urease activity was statistically significant higher in Polish fen and raised bog than in above Siberia peatlands. Błońska [2010] found differences of urease activity in the studied peat types which can be associated with statistically significant differentiation in the content of $\mathrm{C}$ and $\mathrm{N}$. Differentiation of organic $\mathrm{C}$ and total $\mathrm{N}$ in the examined soils results from different botanical composition of partly decayed vegetation matter.

We observed statistically significant differences for activity of xanthine oxidase between Sphagnum (acrotelm - $5.43 \mu \mathrm{mol} \cdot \mathrm{s}^{-1} \cdot \mathrm{kg}^{-1}$; catotelm $-4.37 \mu \mathrm{mol} \cdot \mathrm{s}^{-1} \cdot \mathrm{kg}^{-1}$ ) and Carex dominated peat soils (acrotelm $2.92 \mu \mathrm{mol} \cdot \mathrm{s}^{-1} \cdot \mathrm{kg}^{-1}$; catotelm $-2.33 \mu \mathrm{mol} \cdot \mathrm{s}^{-1} \cdot \mathrm{kg}^{-1}$ ) in both layers (table 3). Statistically higher activity of xanthine oxidase are in line with higher concentrations of Fe(III) in Sphagnum than in Carex peat soils and indicate higher oxidizing properties of Sphagnum peat soils. Furthermore, Szajdak et al. [2012b] reported higher activity of xanthine oxidase in Polish fen (from 5.44 to $8.16 \mu \mathrm{mol} \cdot \mathrm{s}^{-1} \cdot \mathrm{kg}^{-1}$ ) in comparison with West Siberian peatlands as described above. Higher activity of this enzyme in Sphagnum than in Carex dominated peat soils contribute to the increase degradation of peptides and purine basis which may indicate the dominance of catabolic processes. Peptides, purine basis and aldehydes may be fully degraded and complicated ones are perhaps partially oxidized, thereby generating intermediates. Formed compounds undergo heteropolycondensation giving macromolecules of humic substances. The formation of huminoproteides complexes leads to the inhibition of proteolysis, while humic acids stimulate the deamination of amino acids [Łoginow, 1967].

Our investigations showed that activity of phenol oxidase, peroxidase and nitrate reductase did not differ significantly between Sphagnum and Carex dominated peat soils in both layers (table 3 ). The activity of phenol oxidase in Sphagnum dominated peat soils at the depth $0-50 \mathrm{~cm}$ and $50-100 \mathrm{~cm}$, was $8.62 \mu \mathrm{mol} \cdot \mathrm{s}^{-}$ ${ }^{1} \cdot \mathrm{kg}^{-1}$ and $8.12 \mu \mathrm{mol} \cdot \mathrm{s}^{-1} \cdot \mathrm{kg}^{-1}$, respectively (table 3). However, the activity of phenol oxidase in Carex dominated peat soils of appropriate layers was $9.40 \mu \mathrm{mol} \cdot \mathrm{s}^{-1} \cdot \mathrm{kg}^{-1}$ and $8.91 \mu \mathrm{mol} \cdot \mathrm{s}^{-1} \cdot \mathrm{kg}^{-1}$, respectively. Szajdak et al. [2012a and 2012b] have shown statistically significantly higher activity of phenol oxidase in fen and raised bog in Polish than West Siberian peatlands. In addition, Willams et al. [2000] reported that activity of phenol oxidase in Sphagnum and Carex peat was strongly dependent on the botanical composition, wetland type, $\mathrm{pH}$ than aeration and water level. These authors found positive correlation 
between the activity of phenol oxidase and soluble phenolic concentrations in Carex wetland. However, Efremova and Ovchinnikova [2008] documented statistically significantly less oxidoreductase activity in zone of $10-30 \mathrm{~cm}$.

The data of peroxidase activities ranged from 1.81 to $1.99 \mathrm{nmol} \cdot \mathrm{s}^{-1} \cdot \mathrm{kg}^{-1}$ in Sphagnum and from 2.24 to $2.56 \mathrm{nmol} \cdot \mathrm{s}^{-1} \cdot \mathrm{kg}^{-1}$ in Carex dominated peat soils (table 3). The results of Szajdak et al. [2012a and 2012b] from Polish fen and raised bogs are in line with that data. Furthermore, Jassey et al. [2012] reported that peroxidase activities from Sphagnum mosses were 1000-fold higher irrespective of season and sampling areas. Efremova and Ovchinnikova [2007] observed seasonal average peroxidase activities for the layers in the $0-30 \mathrm{~cm}$ soil profile. They postulated that, irrespective of drainage conditions, the highest oxidoreductase activity was measured in the $0-5 \mathrm{~cm}$ layer but it significantly decreased with depth due to natural factors like high soil moisture, low temperature, and low microbial activity. However, oxidoreductase activity increased with drainage depth. Sinsabaugh [2010] showed no correlation between peroxidase activity and soil organic matter content. He suggested that high in situ oxidative activities limit soil organic matter accumulation.

Our results showed that the activity of nitrate reductase ranged from 0.02 to $0.03 \mathrm{nmol} \cdot \mathrm{s}^{-1} \cdot \mathrm{kg}^{-1}$ in both layers of Sphagnum and Carex dominated peat soils (table 3). However, the activity of nitrate reductase in Polish fen and raised bog were statistically significant higher than in West Siberian peatlands [Szajdak et al., $2012 \mathrm{a}$ and $2012 \mathrm{~b}$ ]. In the process of denitrification, dissimilatory nitrate reductase catalyses the first step of denitrification by reducing nitrate to nitrite ions [Singh and Kumar, 2008]. Under natural conditions, nitrification is limited by low pH in Sphagnum-mires resulting in low nitrate ions production and low denitrification activity and in pristine Sphagnum-mires function as nitrogen sink ecosystems than nitrogen source for the atmosphere [Koops et al., 1996; Francez et al., 2011].

\section{CONCLUSIONS}

In the conditions of West Siberia the investigation showed differences in biochemical, chemical and physical parameters between Sphagnum and Carex dominated peat soils of acrotelm and catotelm.

The studies demonstrated that concentration of total nitrogen is directly proportional to activity of urease, and ammonium ions, bulk density and inversely proportional to $\mathrm{C} / \mathrm{N}$, porosity and moisture which indicates lower nitrogen transformation and decrease processes of organic matter decomposition in Sphagnum than in Carex dominated peat soils.

Statistically significant lower activity of urease was determined in acrotelm and catotelm of Sphagnum than in Carex dominated peat soils in West Siberian peatlands. It suggests lower rate of nitrogen transformation in Sphagnum than in Carex dominated peat soils. Decrease activities of urease in Sphagnum than in Carex dominated peat soils are in line with the values of bulk density, ammonium and total nitrogen.

Under limited oxygen, low $\mathrm{pH}$ and phenol oxidase activity slows down degradation of phenolic compounds in peat soils. Phenolic accumulation in soil solution can inhibit urease activity in Sphagnum dominated peat soils. This enzyme release ammonium through urea hydrolysis and are essential in the chain of amino compounds. Lower urease activity is related to anabolic processes at the depth of 0-50 and 50-100 $\mathrm{cm}$ in Sphagnum dominated peat soils.

The increase of xanthine oxidase activity in Sphagnum dominated peat soils may be related to rise porosity, concentrations of dissolved organic carbon, and ferric ions. These results indicate that the dominance oxidative properties in Sphagnum than in Carex dominated peat soils were found to be more effective for the degradation of purine basis and peptides and higher rate anabolic than catabolic processes.

The studies showed that organic matter from Sphagnum dominated peat soils has undergone the most significant biochemical and chemical transformation (oxidation hydrolysis and polymerization) with the accumulation of resistant compounds compared to the organic matter from Carex dominated peat soils.

\section{ACKNOWLEDGEMENTS}

We would like to acknowledge the grants founded by Polish Ministry of Education No N N305 121934 and N N305 320436; DEC 2013/09/B/NZ9/03169 founded by the Polish National Sciences Centre; 
Russian Ministry of Education and Science (W 02.740.11.0325), RFFR (W 09-05-00235); “Peat AcroCato", supported by the FP7 Interact - Transnational Access.

\section{LITERATURE}

Aerts R., Verhoeven J.T.A., Whigham D. 1999. Plant-mediated controls on nutrient cycling in temperate fens and bogs // Ecology. V. 80. P. 2170-2181.

Arkhipov V.S., Maslov S.G. 1998. Composition and properties of typical peat central part of Western Siberia // Chemistry of

Plant Raw Materials V. 4. P. 9-16.

Bartha R., Bordeleau L. 1969. Cell-free peroxidases in soil // Soil Biol. Biochem. V. 1. P. 139-143.

Beilman D.W., MacDonald G.M., Smith L.C., Reimer P.J. 2009. Carbon accumulation in peatlands of West Siberia over the last 2000 years // Global Biogeochem. Cy. V. 23. GB1012. DOI:10.1029/2007GB003112.

Bejger R., Gołębiowska D., Nicia P. 2011. Obecność substancji humusopodobnych w roślinności torfotwórczej [The presence of humic-like substances in peat forming plants] // Woda-Środowisko-Obszary Wiejskie V. 11. № 1. P. 21-29.

Błońska E. 2010. Enzyme activity in forest peat soils // Folia For. Pol. Ser. A. V. 52. № 1. P. 20-25.

Borren W., Bleuten W., Lapshina E.D. 2004. Holocene peat and carbon accumulation rates in the southern taiga of western Siberia // Quat. Res. V. 61. P. 42-51.

Bozkurt S., Lucisano M., Moreno L., Neretnieks I. 2001. Peat as a potential analogue for the long-term evolution in landfills // Earth-Sci. Rev. V. 53. P. 95-147.

Chanton J.P., Glaser P.H., Chasar L.S., Burdige D.J., Hines M.E., Siegel D.I., Tremblay L.B., Cooper W.T. 2008. Radiocarbon evidence for the importance of surface vegetation on fermentation and methanogenesis in contrasting types of boreal peatlands // Global Biogeochem. Cy. V. 22. P. 1-11. GB4022. DOI:10.1029/2008GB003274.

Clymo R.S. 1992. Productivity and decomposition of peatland ecosystems // Peatland Ecosystems and Man: an Impact Assessment / Bragg O.P. et al. (eds.). University of Dundee and International Peat Society. P. 3-16.

Clymo R.S., Hayward P.M. 1982. The ecology of Sphagnum // Bryophyte ecology / Smith A.J.E. (Ed.). London, New York: Hapman and Hall. P. 229-289.

Dobrovol'skaya T.G., Golovchenko A.V., Zvyagintsev D.G. 2014. Analysis of ecological factors limiting the destruction of high-moor peat // Eurasian Soil Sci. V. 47. № 3. P. 182-193.

Efremova T.T, Ovchinnikova T.M. 2007. Oxidoreductase activity of peat soils as an indicator of the degree of biochemical transformation of drained and forested bogs in west Siberia // Biol. Bull. V. 34 № 3 P. 297-302. DOI:10.1134/S1062359007030132

Efremova T.T, Ovchinnikova T.M. 2008. Seasonal oxidoreductase activity in reclaimed peat soils in connection with hydrothermal conditions of environment // Contemp. Probl. Ecol. V. 1 № 3 P. 346-352.

Francez A-J., Pinay G., Josselin N., Williams B.L. 2011. Denitrification triggered by nitrogen addition in Sphagnum magellanicum peat // Biogeochem. V. 106. № 3. P. 435-441. DOI 10.1007/s10533-010-9523-5

Glenn A.J., Flanagan L.B., Syed K.H., Carlson P.J. 2006. Comparison of net ecosystem $\mathrm{CO}_{2}$ exchange in two peatlands in western Canada with contrasting dominant vegetation, Sphagnum and Carex // Agri. Forest Meteorol. V. 140. P. 115-135.

Golovchenko A.V., Tikhonova E. Yu., Zvyagintsev D.G. 2007. Abundance, biomass, structure, and activity of the microbial complexes of minerotrophic and ombrotrophic peatlands // Microbiology V. 76. №. 5. P. 630-637.

Holden J., Burt T.P. 2003. Hydrological studies on blanket peat: the significance of the acrotelm-catotelm model // J. Ecol. V. 91. P. 86-102.

Inisheva L.I., Zemtsov A.A., Novikov S.M. 2011. Vasugan Mire. Natural conditions, structure and functioning // Tomsk State Pedagogical University Press. P. 1-160.

Jassey V.E.J., Chiapusio G., Gilbert D., Toussaint M.L., Binet P. 2012. Phenoloxidase and peroxidase activities in Sphagnum-dominated peatland in a warming climate // Soil Biol. Biochem. V. 46. P. 49-52. DOI:10.1016/j.soilbio.2011.11.011

Joosten H., Clarke D. 2002. Wise use of mires and peatlands-background and principles including a framework for decisionmaking. Saarijärvi: International Mire Conservation Group and International Peat Society. 304 p.

Kandeler E. 1996. Nitrate reductase activity // Methods in soil biology / Schinner F. et al. (eds.). Berlin Heidelberg: SpringerVerlag. P. 176-179.

Kang H., Freeman C. 1999. Phosphatase and arylsulphatase activities in wetland soils: annual variation and controlling factors // Soil Biol. Biochem. V. 31. P. 449-454.

Koerselman W., van Kerkhoven M.B., Verhoeven J.T.A. 1993. Release of inorganic N, P and K in peat soils; effect of temperature, water chemistry and water level // Biogeochemistry V. 20. P 63-81.

Koops J.G., Oenema O., van Beusichem M.L. 1996. Denitrification in the top and sub soil of grassland on peat soils // Plant Soil. V. 184. P. 1-10.

Krawczyński J. 1972. Diagnostyka enzymologiczna w medycynie praktycznej. [Enzymatologic diagnostic in practical medicine]. Warsaw: PZWL. P. 182-184. (in Pol.)

Lappalainen E. 1996. Global peat resources. Jyska, Finland: International Peat Society. 358 p.

Limpens J., Heijmans M.M.P.D., Berendse F. 2006. The nitrogen cycle in boreal peatlands // Boreal Peatland Ecosystems / Wieder R.K., Vitt D.H. (eds.). Berlin/Heidelberg: Springer. Ecological Studies. Vol. 188. P. 195-230.

Lovley D.R., Anderson R.T. 2000. The influence of dissimilatory metal reduction on the fate of organic and metal contaminants in the subsurface // J. Hydrol. V. 8. P. 77-88.

Łoginow W. 1967. Wpływ kwasów huminowych na proces dezaminacji aminokwasów. [Effect of humic acid on the process of deamination of amino acids] // Pamietnik Puławski. V. 29. P. 1-43.

Mäkilä M. 2011a. The sufficiency of peat for energy use on the basis of carbon accumulation // Geoscience for Society 125th Anniversary Volume. Geological Survey of Finland / Nenonen K., Nurmi P.A. (Ed.). Special Paper V. 49. P. $163-170$.

Mäkilä M. 2011b. Carbon accumulation in pristine and drained mires // Geoscience for Society 125th Anniversary Volume. Geological Survey of Finland / Nenonen K., Nurmi P.A. (Ed.). Special Paper V. 49. P. 171-177. 
Mäkilä M., Goslar T. 2008. The carbon dynamics of surface peat layers in southern and central boreal mires of Finland and Russian Karelia // Suo. V. 59. № 3. P. 49-69.

Malmer N., Wallén B. 2005. Nitrogen and phosphorus in mire plants: variation during 50 years in relation to supply rate and vegetation type // Oikos. V. 109. P. 539-554.

Minczewski L., Marczenko Z. 1976. Chemia analityczna. [Analytical Chemistry]. Warsaw: PWN. 375 p. (in Pol.)

Nungesser M.K. 2003. Modelling microtopography in boreal peatlands: hummocks and hollows // Ecol. Model. V. 165. P. 175-207.

Okruszko H., Piaścik H. 1990. Charakterystyka gleb hydrogenicznych. [Characterization of hydrogenic soils]. Olsztyn: ART. 291 p. (in Pol.)

Paavilainen E., Päivänen J. 1995. Peatland Forestry: ecology and principles // Ecological Studies 111 / Germany, Bedin, Heidelberg: Springer-Verlag. 452 p.

Perucci P., Casucci C., Dumontet S. 2000. An improved method to evaluate the o-diphenol oxidase activity of soil // Soil Biol. Biochem. V. 32. P. 1927-1933.

Repo M.E., Huttunen J.T., Naumov A.V., Chichulin A.V., Lapshina E.D., Bleuten W., Martikainen P.J. 2007. Release of CO 2 and $\mathrm{CH}_{4}$ from small wetland lakes in western Siberia // Tellus V. 59B. P. 788-796.

Ringqvist L., Öborn I. 2002. Cooper and zinc adsorption onto poorly humified Sphagnum and Carex peat // Water Res. V. 36. № 9. P. 2233-2242.

Robinson S.D., Moore T.R. 1999. Carbon and peat accumulation over the past 1200 years in a landscape with discontinuous permafrost, northwestern Canada // Global Biogeochem. Cy. V. 13. № 2. P. 591-601.

Savelyeva A.V. Yudina N.V. 2003. Changing the chemical composition of the marsh plants during peat formation // Chemistry of Plant Raw Materials V. 3. P. 17-20.

Savicheva O.G., Inisheva L.I. 2008. Biochemical activity of the peat soil of River Marsh ecosystem // Contemp. Prob. Ecol. V. 1. № 6. P. 666-672.

Scheffer R.A., van Logtestijn R.S.P., Verhoeven T.A. 2001. Decomposition of Carex and Sphagnum litter in two mesotrophic fens differing in dominant plant species // Oikos V. 92. № 1. P. 44-54.

Singh D.K., Kumar S. 2008. Nitrate reductase, arginine deaminase, urease a dehydrogenase activities in natural soil (ridges with forest) and in cotton safter cetamiprid treatments // Chemosphere. V. 71. P. 412-418.

Sinsabaugh R.L. 2010. Phenol oxidase, peroxidase and organic matter dynamics of soil // Soil Biol. Biochem. V. 42. P. 391404.

Sinsabaugh R.L., Lauber Ch.L., Weintraub M.N., Ahmed B., Allison S.D., Crenshaw C.H., Contosta A.R., Cusack D., Frey S., Gallo M.E., Gartner T.B., Hobbie S.E., Holland K., Keeler B.L., Powers J.S., Stursova M., Takacs-Vesbach C., Waldrop M.P., Wallenstein M.D., Zak D.R., Zeglin L.H. 2008. Stoichiometry of soil enzyme activity at global scale // Ecol. Lett. V. 11. P. 12521264.

Smolander A., Kitunen V. 2002. Soil microbial activities and characteristics of dissolved organic C and N in relation to tree species // Soil Biol. Biochem. V. 34. P. 651-660.

Spoelstra J., Schiff S.L., Semkin R.G., Jeffries D.S., Elgood R.J. 2010. Nitrate attenuation in small temperate wetland following forest harvest // Forest Ecol. Manag. V. 259. P. 2333-2341.

Steinmann P., Shotyk W. 1997. Chemical composition, pH, and redox state of sulfur and iron in complete vertical porewater profiles from two Sphagnum peat bogs, Jura Mountains, Switzerland // Geochim. Cosmochim. Acta. V. 61. P. 1143-1163.

Szajdak L., Maryganova V., Meysner T., Tychinskaja L. 2002. Effect of shelterbelt on two kinds of soils on the transformation of organic matter // Environ. Int. V. 28. № 5. P. 383-392.

Szajdak L.W., Gaca W. 2010. Nitrate reductase activity in soil under shelterbelt and adjoining cultivated field // Chem. Ecol. V. 26. № 4. P. 123-134.

Szajdak L.W., Gaca W. 2011. Denitrification in shelterbelts and adjoining cultivated fields // Shelterbelts: efficient element of the landscape. Chemical and biochemical investigations of ground water and soil / Szajdak L.W. (Ed.). Saarbrücken, Germany: LAP Lambert Academic Publishing. P. 55-66.

Szajdak L.W., Gaca W., Meysner T., Styła K., Maryganova V. 2011a. Enzymes activity and IAA contents in soils // Research methods in plant sciences, Vol. 2, Forestry and agroforestry / Narwal S.S. et al. (eds.). Houston, Texas LLC. USA: Studium Press. V. 1. P. 207-230.

Szajdak L.W., Gaca W., Styła K., Meysner T. 2012a. Changes of enzyme activities in peat profile of Kusowo bog // Necessity of peatlands protection / Szajdak L.W., Gaca W., Meysner T., Styła K., Szczepański M. (eds.). Poznań: Wyd. Prodruk. P. 47-60.

Szajdak L.W., Meysner T., Styła K. 2011b. Biochemical and chemical characterization of soils under shelterbelts and adjoining cultivated fields // Shelterbelts: efficient element of the landscape. Chemical and biochemical investigations of ground water and soil / Szajdak L.W. (Ed.). Saarbrücken, Germany: LAP Lambert Academic Publishing. P. 33-53.

Szajdak L.W., Styła K., Gaca W., Meysner T., Szczepański M., Nowak J.S. 2013. Biochemical and chemical properties of commercial growing media, fen and raised bog // ProEnvironment. V. 6. № 14. P. 247-253.

Szajdak L.W., Styła K., Meysner T., Gaca W., 2012b. Choice enzymes participating in oxydoreduction properties in peat profile of Stążka Mire // Necessity of peatlands protection / Szajdak L.W., Gaca W., Meysner T., Styła K., Szczepański M. (eds.). Poznań: Wyd. Prodruk. P. 61-75.

Szajdak L.W., Szatyłowicz J., Kõlli R. 2011c. Peats and peatlands, physical properties // Encyclopedia of Agrophysics / Gliński J. et al. (eds.). Institute of Agrophysics, Polish Academy of Sciences, Lublin, Poland: Springer. P. 551-555.

Ulanowski T.A., Branfireun B.A. 2013. Small-scale variability in peatland pore-water biogeochemistry, Hudson Bay Lowland, Canada // Sci. Total Environ. V. 454-455. P. 211-218.

van Breemen N. 1995. How Sphagnum bogs down other plants // Trends Ecol. Evol. V. 10. P. 270-275.

von Post L. 1922. Sveriges Geologiska Undersöknings torvinventering och några av dess hitills vunna resultat // Svenska Mosskulturföreningens Tidskrift V. 36. P. 1-27. (in Swedish)

Westbrook Ch.J., Devito K.J., Allan C.J. 2006. Soil N cycling in harvested and pristine Boreal forests and peatlands // Forest Ecol. Manag. V. 234. P. 227-237. 
Williams Ch.J., Shingara E.A., Yavitt J.B. 2000. Phenol oxidase activity in peatlands in New York State: response to summer drought and peat type // Wetlands V. 20. № 2. 416-421.

\title{
ФИЗИЧЕСКИЕ, ХИМИЧЕСКИЕ И БИОХИМИЧЕСКИЕ СВОЙСТВА СФАГНОВЫХ И ОСОКОВЫХ ТОРФОВ ЗАПАДНОЙ СИБИРИ
}

\author{
Шайдак Л.В. ${ }^{1}$, Лапиина Е.Д. ${ }^{2}$, Гака В. ${ }^{1}$, Стыла K. $^{1}$, Мейснер $T^{1}$, Шчепански М. ${ }^{1}$, Заров Е.А. ${ }^{2}$
}

${ }^{1}$ Институт агрокультуры и лесов, Польша

${ }^{2}$ Югорский государственный университет, Ханты-Мансийск, Российская Федерация

Было проведено сравнительное исследование физических, химических и биохимических свойств акротелма (торфогенный горизонт) и катотелма (горизонт накопления торфа) участков с доминированием сфагновых и осоковых торфов в Западной Сибири. Концентрация общего азота прямо пропорциональна содержанию нитрат-ионов и ионов аммония, активности уреазы, объемной плотности, и обратно пропорционально отношению $\mathrm{C} / \mathrm{N}$, пористости и влажности в обоих рассматриваемых типах почв. Полученные результаты указывают на низкий уровень азотной трансформации и замедление процессов разложения органического вещества в сфагновых и осоковых типах почв. Исследование показало, что сфагновые торфа претерпевают значительные химические и биохимические трансформации (окисление, гидролиз, полимеризация) с аккумуляцией наиболее устойчивых соединений по сравнению с органическим веществом осоковых торфов.

Ключевые слова: сфагновые и осоковые торфяные почвы, ферментативная активность, физические, химические и биохимические свойства. 


\section{APPENDIX}

Table 1. Location, botanical composition of vegetation cover, type of peat and decomposition degree of Sphagnum and Carex dominated peat soils

\begin{tabular}{|c|c|c|c|c|c|}
\hline $\begin{array}{c}\text { Place of } \\
\text { sampling }\end{array}$ & $\begin{array}{c}\text { GPS } \\
\text { Localisation }\end{array}$ & Botanical composition of vegetation cover of investigated places & $\begin{array}{l}\text { Depth } \\
\text { cm }\end{array}$ & $\begin{array}{l}\text { Type of peat } \\
\text { based on } \\
\text { macrofossil } \\
\text { analysis }\end{array}$ & $\begin{array}{l}\text { Degree of } \\
\text { decomposition } \\
(\text { von Post })\end{array}$ \\
\hline \multicolumn{6}{|c|}{ Sphagnum dominated peat soils } \\
\hline \multirow{2}{*}{ KM2 } & \multirow{2}{*}{$\begin{array}{l}\text { N } 60^{\circ} 89^{\prime} 50.5^{\prime \prime} \\
\text { E } 68^{\circ} 69^{\prime} 20.9^{\prime \prime}\end{array}$} & \multirow{2}{*}{$\begin{array}{l}\text { Sphagnum angustifolium, S. fuscum, S. magellanicum, Ledum palustre, Rubus chamaemorus, } \\
\text { Chamaedaphne calyculata, Betula nana, Pinus sylvestris, Pinus sibirica. }\end{array}$} & $0-50$ & Sphagnum & $\mathrm{H} 1$ \\
\hline & & & $50-100$ & Sphagnum & $\mathrm{H} 2$ \\
\hline \multirow{2}{*}{ KM3 } & \multirow{2}{*}{$\begin{array}{l}\text { N } 60^{\circ} 53^{\prime} 43.88^{\prime \prime} \\
\text { E } 68^{\circ} 40^{\prime} 46.84^{\prime \prime}\end{array}$} & \multirow{2}{*}{$\begin{array}{l}\text { Sphagnum fuscum, Ledum palustre, Chamaedaphne calyculata, Cladonia sp., Rubus } \\
\text { chamaemorus, Pinus sylvestris, Betula nana. }\end{array}$} & $0-50$ & Sphagnum & $\mathrm{H} 1$ \\
\hline & & & $50-100$ & Sphagnum & $\mathrm{H} 2$ \\
\hline \multirow{2}{*}{ KM4 } & \multirow{2}{*}{$\begin{array}{l}\text { N } 60^{\circ} 53^{\prime} 44.22^{\prime \prime} \\
\text { E } 68^{\circ} 40^{\prime} 12.47^{\prime \prime}\end{array}$} & \multirow{2}{*}{$\begin{array}{l}\text { Sphagnum fuscum, Ledum palustre, Chamaedaphne calyculata, Rubus chamaemorus, } \\
\text { Oxycoccus palustris, Pinus sylvestris. }\end{array}$} & $0-50$ & Sphagnum & H1 \\
\hline & & & $50-100$ & Sphagnum & H1 \\
\hline \multirow{2}{*}{ KM10 } & \multirow{2}{*}{$\begin{array}{l}\text { N } 60^{\circ} 53^{\prime} 29.12^{\prime \prime} \\
\text { E } 68^{\circ} 41^{\prime} 33.50^{\prime \prime}\end{array}$} & \multirow{2}{*}{$\begin{array}{l}\text { Sphagnum capillifolium, S. angustifolium, S. fuscum, Ledum palustre, Chamaedaphne } \\
\text { calyculata, Oxycoccus microcarpus, Vaccinium uliginosum, Vaccinium vitis-idaea, Rubus } \\
\text { chamaemorus, Pinus sylvestris, Pinus sibirica, Betula nana. }\end{array}$} & $0-50$ & Sphagnum & $\mathrm{H} 1$ \\
\hline & & & $50-100$ & Sphagnum & $\mathrm{H} 2$ \\
\hline KM17 & $\begin{array}{l}\mathrm{N} 60^{\circ} 52^{\prime} 33.1^{\prime \prime} \\
\mathrm{E} 68^{\circ} 36^{\prime} 55.3^{\prime \prime}\end{array}$ & $\begin{array}{l}\text { Sphagnum magellanicum, S. angustifolium, Chamaedaphne calyculata, Oxycoccus palustris, } \\
\text { Andromeda polifolia, Eriophorum vaginatum, Betula pendula. }\end{array}$ & $0-50$ & Sphagnum & $\mathrm{H} 1$ \\
\hline \multirow{2}{*}{ KM18 } & \multirow{2}{*}{$\begin{array}{l}\text { N } 60^{\circ} 53^{\prime} 43.5^{\prime \prime} \\
\text { E } 68^{\circ} 38^{\prime} 20.4^{\prime \prime}\end{array}$} & \multirow{2}{*}{$\begin{array}{l}\text { Sphagnum papillosum, Carex limosa, Rhynchospora alba, Drosera anglica, Scheuchzeria } \\
\text { palustre, Menyanthes trifoliata, Oxycoccus microcarpus, Eriophorum russeolum, Andromeda } \\
\text { polifolia. }\end{array}$} & $0-50$ & Sphagnum & $\mathrm{H} 1$ \\
\hline & & & $50-100$ & Sphagnum & $\mathrm{H} 1$ \\
\hline \multirow{3}{*}{ KM1 } & & Carex dominated peat soils & & & \\
\hline & N $60^{\circ} 53^{\prime} 41.6^{\prime \prime}$ & $\begin{array}{l}\text { Sphagnum fuscum, S. capillifolium, S. magellanicum, S. angustifolium, Ledum palustre, } \\
\text { Rubus chamaemorus, Carex globularis, Chamaedaphne calyculata, Vacinium vitis-idaea, } \\
\text { Oxycoccus microcarpus, Vaccinium myrtillus, Pleurozium schreberi, Polytrichum strictum, }\end{array}$ & $0-50$ & sedge woody & $\mathrm{H} 2$ \\
\hline & Е $68^{\circ} 41^{\prime} 51.9^{\prime \prime}$ & Dicranum polysetum, Aulacomnium palustre, Pinus sylvestris, $P$. sibirica. & $50-100$ & $\begin{array}{l}\text { woody-cotton } \\
\text { grass }\end{array}$ & $\mathrm{H} 3 / \mathrm{H} 4$ \\
\hline \multirow{2}{*}{ KM15 } & \multirow{2}{*}{$\begin{array}{l}\text { N } 60^{\circ} 53^{\prime} 55.2^{\prime \prime} \\
\text { E } 68^{\circ} 44^{\prime} 59.9^{\prime \prime}\end{array}$} & $\begin{array}{l}\text { Carex juncea, Comarum palustre, Phalaris arundinacea, Lactuca sibirica, Calamagrostis } \\
\text { stricta (C. neglecta), C. phragmitoides, Lythrum salicaria, Lysimachia thyrsiflora, L. }\end{array}$ & $0-50$ & sedge woody & H5 \\
\hline & & $\begin{array}{l}\text { vulgaris, Rumex aquatilis, Galium ruprechtii, Lathyrus palustris, Anemone dichotoma, Betula } \\
\text { pubescens, Salix pentandra, Salix cinerea. }\end{array}$ & $50-100$ & sedge woody & H6 \\
\hline \multirow{2}{*}{ KM16 } & \multirow{2}{*}{$\begin{array}{l}\text { N } 60^{\circ} 52^{\prime} 35.9^{\prime \prime} \\
\text { E } 68^{\circ} 36^{\prime} 46.7^{\prime \prime}\end{array}$} & \multirow[t]{2}{*}{$\begin{array}{l}\text { Carex rostrata, C. lasiocarpa, C. limosa, S. riparium, Menyanthes trifoliate, Lysimachia } \\
\text { thyrsiflora, Eriophorum vaginatum, Betula pendula, B. pubescens. }\end{array}$} & $0-50$ & sedge-Sphagnum, & $\mathrm{H} 2$ \\
\hline & & & $50-100$ & $\begin{array}{l}\text { herbaceous } \\
\text { (Equisetum) }\end{array}$ & $\mathrm{H} 2$ \\
\hline KM17 & $\begin{array}{l}\text { N } 60^{\circ} 52^{\prime} 33.1^{\prime \prime} \\
\text { E } 68^{\circ} 36^{\prime} 55.3^{\prime \prime}\end{array}$ & $\begin{array}{l}\text { Sphagnum magellanicum, S. angustifolium, Chamaedaphne calyculata, Oxycoccus palustris, } \\
\text { Andromeda polifolia, Eriophorum vaginatum, Betula pendula. }\end{array}$ & $50-100$ & $\begin{array}{l}\text { sedge- } \\
\text { Scheuchzeria }\end{array}$ & $\mathrm{H} 1$ \\
\hline
\end{tabular}

KM1, KM2, KM3, KM4, KM10, KM15, KM16, KM18, KM17 - Mukhrino Field Station 
Table 2. Mean contents and ranges (italics) of chemical compounds, physical parameters, enzyme activities in Sphagnum and Carex dominated peat soils in 0-50 cm and $50-100 \mathrm{~cm}$ layers

\begin{tabular}{|c|c|c|c|c|}
\hline \multirow{2}{*}{ Parameters } & \multicolumn{2}{|c|}{ Sphagnum dominated peat soils } & \multicolumn{2}{|c|}{ Carex dominated peat soils } \\
\hline & $0-50 \mathrm{~cm}$ & $50-100 \mathrm{~cm}$ & $0-50 \mathrm{~cm}$ & $50-100 \mathrm{~cm}$ \\
\hline $\mathrm{pH}$ in $1 \mathrm{~N} \mathrm{KCl}$ & $2.40-3.28$ & $2.41-2.77$ & $3.72-4.43$ & $3.75-4.33$ \\
\hline pH in $\mathrm{H}_{2} \mathrm{O}$ & $3.14-3.71$ & $3.30-4.02$ & $4.21-5.32$ & $4.15-4.86$ \\
\hline \multirow{2}{*}{ Moisture \% } & $93.09 \pm 0.56$ & $88.13 \pm 3.92$ & $86.20 \pm 3.85$ & $81.92 \pm 1.90$ \\
\hline & $91.38-94.96$ & $75.02-94.62$ & $80.82-90.32$ & $76.67-92.21$ \\
\hline \multirow{2}{*}{ Bulk density $\mathrm{kg} \cdot \mathrm{m}^{-3}$} & $98.17 \pm 1.00$ & $105.80 \pm 3.02$ & $157.67 \pm 15.98$ & $114.00 \pm 4.35$ \\
\hline & 95.01-101.12 & $97.00-112.05$ & $115.05-178.15$ & $103.00-141.00$ \\
\hline \multirow{2}{*}{ Porosity \% } & $93.00 \pm 0.50$ & $92.57 \pm 0.16$ & $88.88 \pm 3.19$ & $91.90 \pm 0.15$ \\
\hline & $92.70-93.42$ & $91.55-93.41$ & $91.10-92.90$ & $91.24-93.10$ \\
\hline \multirow{2}{*}{ TOC $\mathrm{g} \cdot \mathrm{kg}^{-1}$} & $413.68 \pm 8.45$ & $437.54 \pm 9.00$ & $416.93 \pm 16.65$ & $447.45 \pm 13.73$ \\
\hline & $407.70-437.70$ & $421.40-451.00$ & $353.40-461.10$ & $378.20-449.40$ \\
\hline \multirow{2}{*}{ DOC $\mathrm{g} \cdot \mathrm{kg}^{-1}$} & $15.33 \pm 1.33$ & $14.67 \pm 1.58$ & $14.64 \pm 3.74$ & $10.12 \pm 2.61$ \\
\hline & $12.30-18.09$ & $10.73-17.94$ & $10.51-21.75$ & $7.25-14.90$ \\
\hline \multirow{2}{*}{$N_{\text {total }} \mathbf{g} \cdot \mathbf{k g}^{-1}$} & $12.10 \pm 0.82$ & $11.16 \pm 1.88$ & $13.66 \pm 0.50$ & $16.13 \pm 2.53$ \\
\hline & $6.05-22.74$ & $6.72-16.80$ & 8.96-17.02 & $11.65-20.38$ \\
\hline \multirow{2}{*}{$\mathrm{N}-\mathrm{NH}_{4}{ }^{+} \mathrm{mg} \cdot \mathrm{kg}^{-1}$} & $25.30 \pm 1.27$ & $18.64 \pm 2.47$ & $37.86 \pm 5.40$ & $28.94 \pm 7.00$ \\
\hline & $22.80-30.30$ & $13.02-25.99$ & $8.37-68.70$ & $9.00-37.78$ \\
\hline \multirow{2}{*}{$\mathrm{N}-\mathrm{NO}_{3}{ }^{-} \mathrm{mg} \cdot \mathrm{kg}^{-1}$} & $26.53 \pm 3.87$ & $15.96 \pm 1.18$ & $32.14 \pm 4.96$ & $22.78 \pm 7.12$ \\
\hline & $20.30-42.63$ & $13.02-18.41$ & $11.16-54.24$ & $9.05-33.40$ \\
\hline \multirow{2}{*}{$\mathrm{C} / \mathrm{N}$} & $34.19 \pm 1.05$ & $39.20 \pm 3.56$ & $30.52 \pm 2.10$ & $27.74 \pm 4.26$ \\
\hline & $18.46-62.34$ & $26.29-62.71$ & $20.76-47.58$ & $22.22-42.87$ \\
\hline \multirow{2}{*}{$\mathrm{Fe}(\mathrm{II}) \mathrm{mg} \cdot \mathrm{kg}^{-1}$} & $35.72 \pm 5.09$ & $37.82 \pm 8.88$ & $34.68 \pm 7.83$ & $38.92 \pm 7.74$ \\
\hline & $16.92-49.63$ & $23.27-63.17$ & $15.16-54.48$ & $17.48-57.53$ \\
\hline \multirow{2}{*}{$\mathrm{Fe}\left(\right.$ III) $\mathrm{mg} \cdot \mathrm{kg}^{-1}$} & $30.54 \pm 3.58$ & $37.98 \pm 7.50$ & $33.05 \pm 9.61$ & $26.18 \pm 3.50$ \\
\hline & $17.21-40.49$ & $22.40-57.70$ & $14.24-50.48$ & $15.18-40.49$ \\
\hline \multirow{2}{*}{$\mathrm{Fe}_{\text {total }} \mathrm{mg} \cdot \mathrm{kg}^{-1}$} & $66.26 \pm 8.51$ & $75.81 \pm 16.32$ & $67.73 \pm 15.24$ & $65.10 \pm 12.96$ \\
\hline & $34.13-90.12$ & $45.67-120.87$ & $29.40-104.96$ & $32.66-80.12$ \\
\hline
\end{tabular}

TOC - total organic carbon; DOC - dissolved organic carbon; $\mathrm{N}_{\text {total }}-$ total nitrogen; UA - urease activity; $\bar{x} \pm \Delta X$ - confidence interval of average at confidence level $\alpha=0.05$ for $\mathrm{n}-1$ degree of freedom 
Szajdak L.W. et al. 2016. Physical, chemical and biochemical properties of Western Siberia ... // EDCC. V. 7. № 2. P. 13-25.

Table 3. Mean and ranges (italic) of enzyme activities in Sphagnum and Carex dominated peat soils in 0-50 cm and 50-100 cm layers

\begin{tabular}{|c|c|c|c|c|}
\hline \multirow{2}{*}{ Parameters } & \multicolumn{2}{|c|}{ Sphagnum dominated peat soils } & \multicolumn{2}{|c|}{ Carex dominated peat soils } \\
\hline & $0-50 \mathrm{~cm}$ & $50-100 \mathrm{~cm}$ & $0-50 \mathrm{~cm}$ & $50-100 \mathrm{~cm}$ \\
\hline \multirow{2}{*}{$\mathrm{UA} \mu \mathrm{mol} \cdot \mathrm{s}^{-1} \cdot \mathrm{kg}^{-1}$} & $1.98 \pm 0.30$ & $2.52 \pm 0.15$ & $2.60 \pm 0.15$ & $2.81 \pm 0.08$ \\
\hline & $1.40-2.33$ & $1.53-3.33$ & $1.60-3.20$ & $2.01-4.06$ \\
\hline \multirow{2}{*}{$\mathrm{XOA} \mu \mathrm{mol} \cdot \mathrm{s}^{-1} \cdot \mathrm{kg}^{-1}$} & $5.43 \pm 0.42$ & $4.37 \pm 1.43$ & $2.92 \pm 0.66$ & $2.33 \pm 0.15$ \\
\hline & $4.49-7.08$ & $1.30-8.78$ & $1.83-3.69$ & $1.32-4.55$ \\
\hline \multirow{2}{*}{ POA $\mu \mathrm{mol} \cdot \mathrm{s}^{-1} \cdot \mathrm{kg}^{-1}$} & $8.62 \pm 0.98$ & $8.12 \pm 0.73$ & $9.40 \pm 0.83$ & $8.91 \pm 0.88$ \\
\hline & $5.66-13.73$ & $4.39-10.72$ & $4.66-12.68$ & $3.25-12.66$ \\
\hline \multirow{2}{*}{ PA nmol $\cdot \mathrm{s}^{-1} \cdot \mathrm{kg}^{-1}$} & $1.99 \pm 0.73$ & $1.81 \pm 0.58$ & $2.56 \pm 0.58$ & $2.24 \pm 0.63$ \\
\hline & $0.79-4.94$ & $0.56-3.06$ & $0.87-4.10$ & $1.01-4.30$ \\
\hline \multirow{2}{*}{ NRA nmol $\cdot \mathrm{s}^{-1} \cdot \mathbf{k g}^{-1}$} & $0.03 \pm 0.01$ & $0.02 \pm 0.01$ & $0.03 \pm 0.01$ & $0.02 \pm 0.01$ \\
\hline & $0.01-0.07$ & $0.01-0.05$ & $0.02-0.05$ & $0.01-0.03$ \\
\hline
\end{tabular}

UA - urease activity; XOA - xanthine oxidase activity; POA - phenol oxidase activity; PA - peroxidase activity; NRA - nitrate reductase activity;

$\bar{X} \pm \Delta X$ - confidence interval of average at confidence level $\alpha=0.05$ for $\mathrm{n}-1$ degree of freedom 